\title{
Pregnancy Married in The Perspective of Four Madzhab and Compilation of Islamic Law (KHI)
}

\begin{abstract}
Ahmad Mustarsidin ${ }^{1}$ and Akhmad Khisni ${ }^{2}$
Abstract. Ulama were differed concerning in pregnancy married. Pregnancy married is a marriage that takes place between men with a woman who is pregnant because of adultery. The opinion of the problem in this paper on the pregnancy married in the perspective of four madzhab and compilation of islamic law is not the same. Madzhab Hanafi and Syafi'i absolutely allow pregnancy married, but in terms of intercourse they have different opinions. Hanafi view when marrying is that impregnates the intercourse is allowed after the marriage ceremony without waiting for the wife gave birth to first, but if that is not who got married, the husband should not intercourse his wife to give birth first. Syafi'i found men who married the pregnant woman is absolutely allowed to have intercourse, both the man who impregnated or not. Instead, Maliki and Hanbali implicitly prohibits pregnancy married, had to wait for the woman giving birth. Even in the Hanbali sect imposed additional conditions, the woman should repent significantly to Allah SWT. Both schools of thought have asserted that the law is invalid pregnancy married. The Compilation of Islamic Law has its own opinion. The provisions on pregnancy married in the Compilation of Islamic law under Article 53 which consists of three (3) paragraph.

Keywords: Pregnancy Married, Compilation of Islamic Law.
\end{abstract}

\section{Introduction}

One of the basic human needs is the distribution of biological desire. To be able to properly distribute the biological desire and feel honored, people should follow the religious rules that have been set. Because, in addition to as social beings, humans are creatures of religion. That is, humans have a tendency towards a certain transcendental beliefs, such as belief in a power that is considered to be taller, the Supreme Organize and Perfect, Absolute, and far less of various properties and limitations (deterministic). ${ }^{3}$ As a Muslim, people believe that the Absolute and Perfect and created the entire universe of this feast is Allah.

Associated with the relationship between men and women, Allah has set a way of relating the lawful and correct. Implementation with prescribed (recognized and arranged) marriage institution. Islam even look at the institution of marriage as a way to protect the existence of the human species in a dignified manner. ${ }^{4}$ Through marriage, a husband and wife the ship sailed home together to be able to continue over the generations are clean and feel honored.

\footnotetext{
${ }^{1}$ Students Master Program (S2) of Law UNISSULA worked as a civil servant email: sidinbejo@yahoo.co.id

2 Lecturer of Faculty of Law UNISSULA Semarang

${ }^{3}$ Forum Kalimasada Madrasah Hidayatul Mubtadi-ien Lirboyo Kota Kediri 2010 Kearifan Syariat: Menguak Rasionalitas Syariat dari Perspektif Filosofis Medis dan Sosiohistoris Darul Azka (eds.) Surabaya : Khalista Cet. 2 p. 28.

${ }^{4}$ Masdar Farid Mas' udi 2010 Syarah Konstitusi UUD 1945 dalam Perspektif Islam Jakarta : Pustaka Alvabet Cet. 1, p. 145.
} 
In Indonesia, in the determination of Islamic law, the influence of the of four Madzhab is very large. Many of the results of ijtihad from the schools attended by Muslims in Indonesia. Thus still very relevant when schools are assessed again primarily to address issues that exist in Indonesia wedding today.

In the law of marriage, the result of ijtihad priests founders of schools of the four mujtahid, Imam Abu Hanifa, Imam Malik, Imam Syafi'i and Imam Ahmad ibn Hanbal also different. Among the sub-issues into the realm of fiqh munakahat is pregnancy married problems.

In Indonesia, the influence of the of four Madzhab is still very large, especially the Syafi'i followed the majority of Muslims in Indonesia. However, the three other schools, namely Hanafi, Maliki and Hanbali schools are still many followers. Many ijtihad results of these schools are used by Muslims in Indonesia. Thus today it is still quite relevant to assess the schools mainly to solve the problems existing marriages in Indonesia today, including pregnancy married problems.

In addition to the results of the of four Madzhab of ijtihad, for Indonesian citizens who are Muslims, in matters of marriage should be subject to the provisions of Book I of the Compilation of Islamic Law concerning marriage. Compilation of Islamic Law issued pursuant to Presidential Instruction No. 1 of 1991 to the Minister of Religious Affairs on June 10, 1991 consists of three (3) books, namely on Marriage Book I, Book II of Book III of the Inheritance and endowment.

One of the problems that often arise in the community is the existence of a marriage performed by a man with a woman who is already pregnant beforehand, otherwise known as pregnancy married. This issue is crucial once. All of four Madzhab, namely Hanafi, Maliki, Syafi'i and Hanbali been doing ijtihad in these pregnancy married problems. Similarly, in the compilation of Islamic law, this issue has also been established laws.

Based on the background and the identification of the problem, can be taken formulation of the problem: "How the pregnancy married in the perspective of four madzhab and compilation of islamic law (KHI)?"

\section{Results and Discussion}

\subsection{Understanding of Pregnancy Married}

In etimology, as pregnancy married consist of two (2) words, are married and pregnant. Married means to get mating, while pregnant means that it contains a fetus. While technically, the definition of marriage to marry pregnant is held in which the wife was pregnant first.

Women who marry in a state of pregnancy there are two (2) types, the first woman who divorced her husband in a state of pregnancy either because of divorce $\left(\operatorname{tal}^{\prime}\right)$, khulu', $l i^{\prime} a n^{5}$, fasakh $^{6}$ nor the death of her husband. And the two women who are

\footnotetext{
${ }^{5} \mathrm{Li}^{\prime}$ an is derived from the word la'an (cursing). A form of divorce does not apply in general based on the allegation concerning the husband against his wife of adultery. To reinforce the accusation a husband say four times the oath (though there have been other evidence such as witnesses four male) while he was willing to accept the curse upon herself if there is fraud in the case of the allegations. Totok Jumantoro dan Samsul Munir Amin 2009 Kamus Ilmu Ushul Fikih Jakarta : Amzah Cet. 2 p. 172.
} 
pregnant outside of marriage because of adultery. The pregnant woman who divorced her husband, scholars agree, including of four Madzhab. Imam Abu Hanifa, Imam Malik, Imam Syafi'i and Imam Ahmad bin Hanbal, including the provisions stipulated in the Compilation of Islamic Law, that she does not be married to a freelance her iddah. ${ }^{7}$ The her iddah is until she gave birth, as has been confirmed by Allah in Surah al-Thalaq paragraph (4):

\section{واولات الاحمال اجلهن ان يضعن حملهن}

"And the women who are pregnant, their waiting period of time that is until they give birth." 8

Law was married to pregnant women as it is haram, and the marriage is not valid, as confirmed in the word of Allah in Surah al-Baqarah (235):

\section{ولا تعزموا عقدة النكاح حتى يبلغ الكتاب اجله}

"And do not you determined for marriage, before the expiry of her iddah."

\subsection{The Law of Pregnancy Married}

According madzhab on law of pregnancy married or marry a woman who already is pregnant because of the different legal adultery, following legal exposure of pregnant according to the of four Madzhab and also according to the Islamic Law Compilation (KHI).

Meanwhile, in the view of the four Madzhab and KHI on pregnant laws also vary:

\subsubsection{Hanafi's View about Pregnancy married}

According to the founder of Imam Abu Hanifah, perform the ceremony with pregnant women because of adultery is not tied to marriage is permissible absolute, whether it is to marry the man who impregnated or not impregnated, with no waiting period. ${ }^{10}$ Therefore, the male sperm that menzinainya not need to be respected. ${ }^{11}$ But the issue of permissibility intercourse with him, Imam Abu Hanifa provide details if marries a man who impregnated her is itself, it should immediately intercourse, but if you are

\footnotetext{
${ }^{6}$ Fasakh means unplugging something that is legitimate and formal (formal legal). Fasakh prescribed to reject the harm and allowed for a wife who has been mukallaf or baligh and sensible to do so. Mustofa Hasan 2011 Pengantar Hukum Keluarga Bandung : Pustaka Setia Cet. 1 p. 213.

${ }^{7}$ Iddah is waiting period is the term for a woman waiting period to get married (again) after her husband's death or (her husband) divorce her. (The end of this time) with (because he) bear (if pregnant) quru' (ie 3 times menstruation or 3 times a saint) or with (passing) a couple of months 4 months 10 days (when her husband died). Muhammad ibn Ali ibn Muhammad as-Syaukani Nail alAuthar t.th. Beirut : Dar al-Fikr Juz IV p. 438.

${ }^{8}$ Kementerian Urusan Agama Islam Wakaf Dakwah dan Bimbingan Islam Kerajaan Arab Saudi, op.cit p. 946.

${ }^{9}$ Ibid p. 57-58.

${ }^{10}$ Al-Sayyid Sabiq Ibid.

${ }^{11}$ Muhammad Jawad Mughniyah 2010 Fiqih Lima Mazhab terj. Masykur Afif Muhammad dan Idrus alKaff Jakarta : Lentera p. 474.
} 
marrying is in addition to people who impregnate it must refrain from intercourse until giving birth.$^{12}$

\subsubsection{Maliki's view about Pregnancy married}

In the view of Maliki, can not marry a woman taken in adultery before it is known that the woman is not pregnant (istibra). To find out impregnated the woman is menstruating three times or wait three months. When it is proven that a pregnant woman, then according to Maliki, can not marry the woman implicitly, whether impregnated or not. And when women have been until the completion her iddah, which gave birth to the new should be married. Ijtihad Imam Malik in this case based on the intent of birth of the $3^{\text {rd }}$ verse of Surah al-Nur and hadiths that prohibit fertilize an existing fetus of a woman relationships with others. ${ }^{13}$

\subsubsection{Shafi'is View about Pregnancy married}

According to Imam Syafi'i, the legal marrying women who are not legally married and pregnant by adultery is allowed and not have to wait for delivery. ${ }^{14}$ He argued that the women were pregnant because of adultery instead of the result of the marriage. It is based on that of Personality (Religion) does not consider at all the children born of adultery as dissolution proceeds nasab biological father of the child. Therefore, it may be for him to marry her and intercourse without waiting for the woman gave birth. ${ }^{15}$

Related men are allowed to marry, Imam Syafi'i declare that anyone can marry the woman, whether impregnated or not. This is because of adultery does not affect anything against nasab relationship. Thus, whether impregnated or not, is still the same because not make the relationship between the child of a relationship nasab adultery with her biological father. After the wedding took place, men who marry either impregnated or not allowed to have intercourse with the woman without having to wait for the woman giving birth.

\subsubsection{Hanbali's View about Pregnancy married}

According to the Hanbali, the adulterous woman to undergo mandatory waiting period. ${ }^{16}$ Regarding the legal marrying pregnant women because of adultery, according to the Hanbali school of illegitimate and should not be, but with two conditions:

- Done her iddah period, that is until the woman giving birth.

- The woman should repent of deeds on her zina.

\subsubsection{Compilation of Islamic Law's View concerning marriage Pregnant}

The provisions on pregnancy married in the Compilation of Islamic law under Article 53 which consists of three (3) paragraph. Sounds more such article as follows:

(1) A woman is pregnant, it can be mated with a male who impregnated her.

\footnotetext{
${ }^{12}$ Abdurrahman al-Jaziri op.cit. p. 521.

${ }^{13}$ Al-Sayyid Sabiq Ibid.

14 Ibid.

${ }^{15}$ Abdurrahman ibn Muhammad ibn Husain t.th. Bughyah al-Mustarsyidin Surabaya : Dar Ihya al-Kutub al-Arabiyyah Indonesia p. 201.

16 Muhammad Jawad Mughniyah op.cit. p. 474.
} 
(2) Marriage with pregnant women who referred to in paragraph (1) may be carried out without waiting for the first birth of her child.

(3) With the holding of marriage at the time of the pregnant woman, it is not necessary remarriage after her unborn child was born. ${ }^{17}$

Article 53 paragraph (1) Compilation of Islamic Law states that a woman who is pregnant outside of marriage can be married to a man who got her pregnant. Paragraph (2) states that the marriage of a woman who is pregnant with her pregnant man can be carried out without waiting for the first birth of her child. As for paragraph (3) states that the holding of marriage at the time of the pregnant woman, it is not necessary remarriage children conceived after birth.

\section{Closing}

\subsection{Conclution}

Opinion of the of four Madzhab and related and Compilation of Islamic law is not the same about pregnancy married. Hanafi and Syafi'i absolutely allow pregnancy married, but in terms of intercourse they have different opinions. Hanafi's view when marrying is that impregnates the intercourse is allowed after the marriage ceremony without waiting for the wife gave birth to first, but if that is not who got married, the husband should not intercourse his wife to give birth first. Syafi'i found men who married the pregnant woman is absolutely allowed to have intercourse, both the man who impregnated or not. Instead, Maliki and Hanbali implicitly prohibits pregnancy married, had to wait for the woman giving birth first. Even in the Hanbali sect imposed additional conditions, the woman should repent significantly to Allah SWT. Both schools of thought have asserted that the law is invalid pregnancy married. The Compilation of Islamic Law has its own opinion. The provisions on pregnancy married in the Compilation of Islamic law under Article 53 which consists of three (3) paragraph. Sounds more such article as follows:

- A woman is pregnant, it can be mated with a male who impregnated her.

- Marriage with pregnant women who referred to in paragraph (1) may be carried out without waiting for the first birth of her child.

- With the holding of marriage at the time of the pregnant woman, it is not necessary remarriage after her unborn child was born.

\subsection{Suggestions}

To be more towards legal certainty associated with pregnancy married and do not cause disparities in the law, the author gives suggestions as follows:

- Compilation of Islamic Law should be upgraded to the Act. It's certainly much more binding and more effective implementation of the still in the bleak now that only Presidential Instruction. Ministry of Religious Affairs and the Supreme Court should sit together as early preparation of the Compilation of Islamic Law first in 1988, to construct the legal drafting the Bill Compilation of Islamic Law.

\footnotetext{
17 Departemen Agama 2001 Kompilasi Hukum Islam di Indonesia Jakarta : Direktorat Pembinaan Badan Peradilan Islam p. 33.
} 
- The people should abide by and comply with the provisions of Islamic law and the provisions of the legislation in force including the Compilation of Islamic Law.

\section{Bibliography}

[1] Al-Bashri Abu al-Hasan ' Ali bin Muhammad bin Habib al-Mawardi 1994 Al-Hawi al-Kabir Beirut Dar al-Kutub al-' IImiyah jilid X.

[2] Al-Bukhari Muhammad ibn Ismail t.th. Shahih al-Bukhari jilid VII Semarang : Toha Putera.

[3] Al-Jaziri Abdurrahman 1989 Al-Fiqh ' ala al-Madzahib al-Arba' ah jilid IV Beirut : Dar al-Fikr.

[4] Al-Qurthubi Muhammad ibn Ahmad ibn Rusyd t.th. Bidayah al-Mujtahid wa Nihayah al-Muqtashid Surabaya : Maktabah Dar Ihya' al-Kutub Indonesia Juz II.

[5] Al-Ra' uf Muhammad Abd. t.th. Islam in Concept (Ta' rif bi al-Islam bi al-Lughah al-Injliziyyah) Al-Maktab al-Ta' awuni li al-Da' wah wa Tau' iyah al-Jaliyat bi alZulfa.

[6] Al-Thabary Muhammad ibn Jarir 2001 Jami' al-Bayan 'an Ta' wil Ayi al-Qur' an Beirut : Dar al-Fikr Jilid II.

[7] Amiruddin dan Zainal Asikin 2012 Pengantar Metode Penelitian Hukum Jakarta : Raja Grafindo Persada Cet. 6.

[8] Anwar Syahrul 2010 Ilmu Fiqh dan Ushul Figh Bogor : Ghalia Indonesia Cet. 1. 